\title{
THE DENTIN-ENAMEL JUNCTION. AN ELECTRON MICROSCOPIC STUDY
}

\author{
Ivet Gil Chavarría*, Antonio González**, José Reyes-Gasga*** \\ * División de Estudios de Posgrado e Investigación de la Facultad de Odontología. UNAM. \\ ** Facultad de Odontología, UNAM; México, D.F. \\ ***Instituto de Física, Depto. Materia Condensada, Circuito de la Investigación, Apartado Postal \\ 20-364 01000, México D.F.
}

This study is related to the dentin-enamel junction of the human tooth. So, the relationship between enamel (96\% inorganic material and $4 \%$ organic material) and dentin (70\% inorganic material and $30 \%$ organic material), organization, microstructure and chemical composition have been investigated. It is very important know the differences of these both tissues and understand how they are maintained together, in special the role of the organic matrix in this junction.

For Light, SEM and TEM sample preparation, human teeth, with conditions of non-carious, permanent, premolar (extracted for orthodontic reasons) and molars principally impacted third molars, were collected. The specimens were fixed and prepared immediately after extraction using different methods. Observation were made with light microscope (LM), transmission electron microscope, but principally scanning electron microscope for a correct characterization of its organic material.

The results obtained in LM allowed to determine the presence of organic material (Fig.1), in contrast with TEM that only showed a free space between enamel and dentin (Fig.3). With SEM we were able to observe the odontoblastic process or some extensions of the odontoblast cell. Moreover, a network of fibrils was presented as part of the organic matrix (Fig.2). Therefore, these results have an important relevance because we can conclude that the junction is formed by chemical, biological and physical processes. Although there is absence of direct contact between enamel and dentin in the microscope images, the presence of amorphous organic material suggests the organization of the organic material within enamel crystals, influencing at the same time the dentin surface structure. Other important characteristic is that both tissues, after their analysis with X-ray diffraction, are formed by the same inorganic material (hydroxyapatite, Ca10(PO4)6(OH)10) with different crystal size and crystal organization. Figure 4 shows some of the chemical map from the junction that allow to identify the element distribution $(\mathrm{C}, \mathrm{Ca}, \mathrm{O}$, and $\mathrm{P})$ in this structures. Further investigations are needed with new techniques to determine the total characterization ultra structural of dentin, enamel, and the organic matrix between them. All this will enlighten on the structure and properties of the dentin-enamel junction, and on their role in an very important in area such as it is the odontology.

References: [1] Ivet Gil Ch."Unión Esmalte-Dentina. Microestructura, composición anatómica y química. Un estudio por Microscopía Electrónica” Fac. Odontología. UNAM 2002

[2] Zamora Montes de Oca "Análisis de la composición y estructura del esmalte y la UAD en dientes humanos" Tesis de Maestría, Fac. Odontología UNAM 1998.

[3] Doukoudakis "Morphologic characteristics of dentin at the dentin-enamel junction as viewed low scanning electron microscopic" J. E. Dent. 1997 9(2) 94-96. 


\section{Acknowledgements:}

We thank the technical assistance from P. Mexía, R. Hernández, J. Cañetas, C. Flores, M. Aguilar, S. Tehuacanero, C. Magaña, A. Sánchez, and I. de Química. UNAM

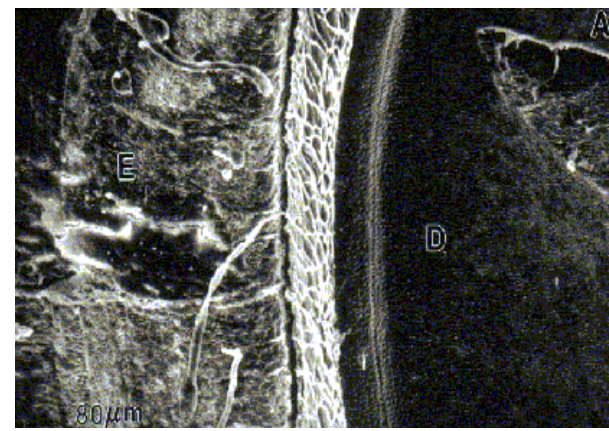

Fig. 1. LM image.

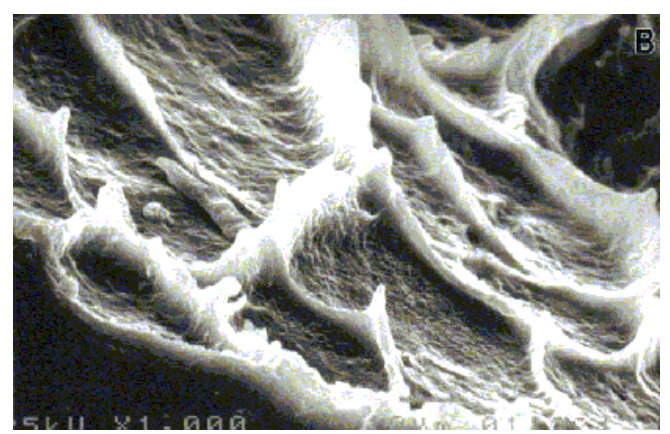

Fig. 2. SEM image (organic material)
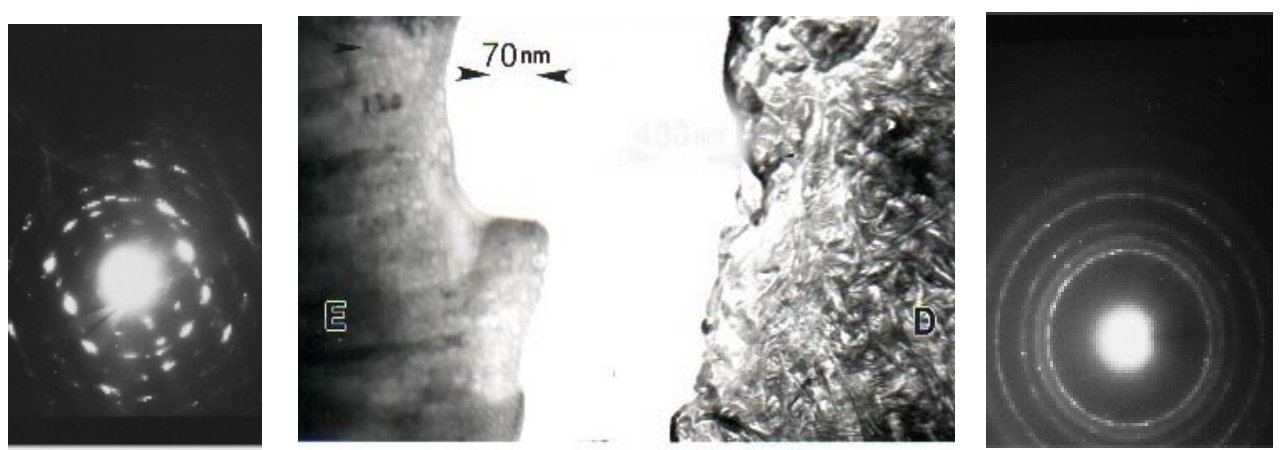

Figs. 2. TEM images. Left enamel, right dentin and pattern diffraction corresponding.
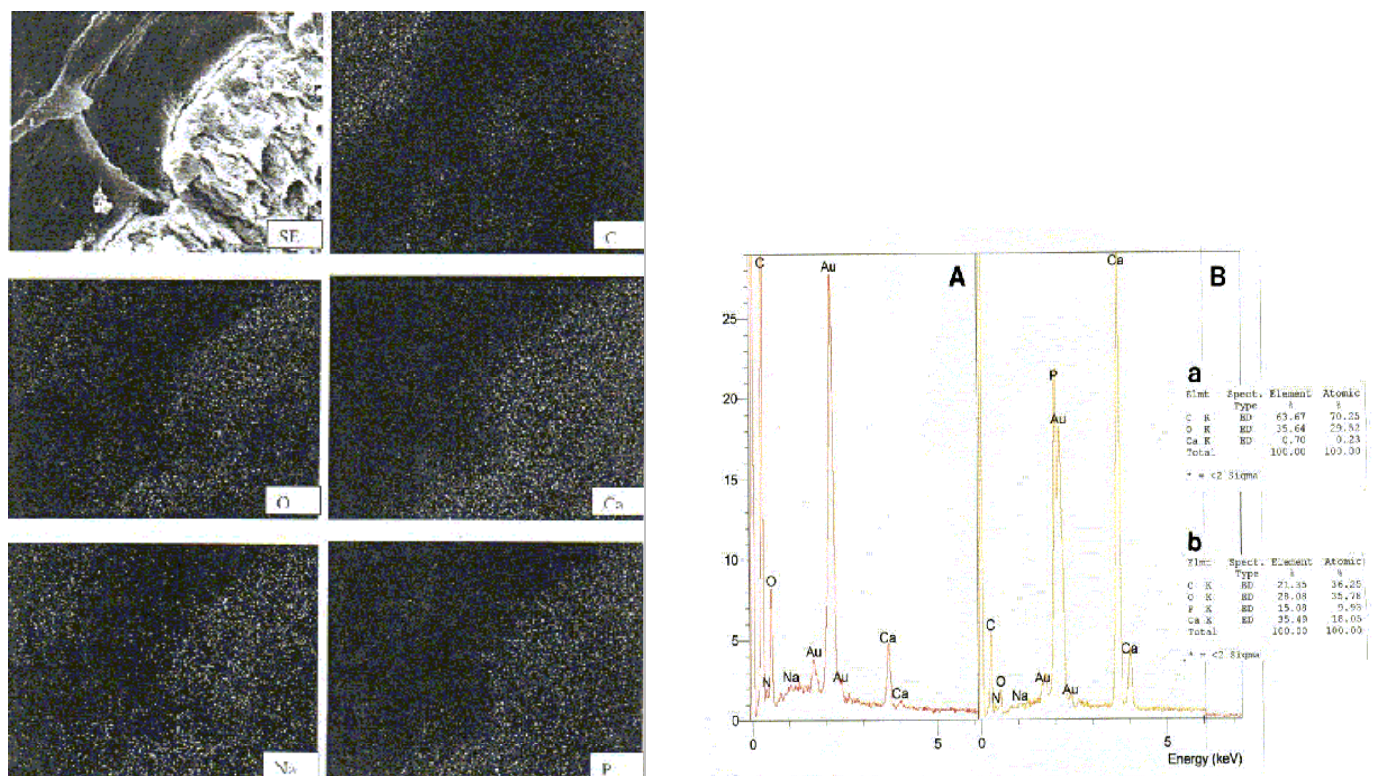

Figs. 4. Chemical map, distribution of elements present in enamel and dentin. 